\title{
Do a science process skills affect on critical thinking in science? Differences in urban and rural
}

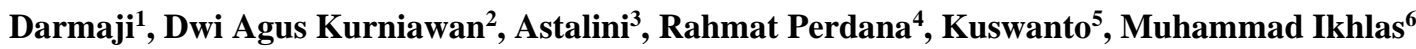 \\ 1,2,3,4 Faculty of Teaching and Education, Universitas Jambi, Indonesia \\ ${ }^{5,6}$ Central Luzon State University, Philippines
}

\section{Article Info \\ Article history: \\ Received Apr 23, 2020 \\ Revised Aug 12, 2020 \\ Accepted Oct 12, 2020}

\section{Keywords:}

Critical thinking

Junior high school

Rural

Science processing skill

Urban

\begin{abstract}
The study used mixed-method design. Sample size of this study was 689 students employed total sampling technique. This study revealed that science process skill of students in learning science whether urban and rural areas are good. The independent sample t-test showed that there was a significance difference in students' science process skill in urban school $(\mathrm{M}=3.175, \mathrm{SD}=$ $0.178)$ and in rural schools $(\mathrm{M}=2.482, \mathrm{SD}=0.182)$; $(\mathrm{t}(687)=18.224$, $\mathrm{p}<0.01$. The independent sample t-test showed that there was a significance difference in students' critical thinking in urban school $(\mathrm{M}=5.058, \mathrm{SD}=$ $0.163)$ and in rural schools $(\mathrm{M}=3.436, \mathrm{SD}=0.152) ; \mathrm{t}(687)=17.224$, $\mathrm{p}<0.001$. Lastly, the regression shows the level of contribution students' science process skill influence as much as $51.5 \%$ for critical thinking. This study was found that student science process skill affects critical thinking in learning science. Moreover, students' science process skill and critical thinking in urban better than rural.
\end{abstract}

This is an open access article under the CC BY-SA license.

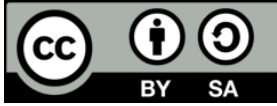

\section{Corresponding Author:}

Dwi Agus Kurniawan,

Faculty of Teaching and Education,

Universitas Jambi,

Jambi, Indonesia.

Email: dwiagus.k@unja.ac.id

\section{INTRODUCTION}

Critical thinking becomes a pattern of thinking that must be possessed by students. Critical thinking is the use of cognitive skills to improve learning outcomes [1], such as analyzing thoughts, analyzing arguments, and solve problems carefully [2]. It is expected that students can think about the ideal of solve the problem. The students can solve problems and phenomena in their lives [3]. Critical thinking is intended, has five indicators; providing simple explanations, building basic skills, making conclusions, making further explanations, and setting strategies and tactics [4]. All students can think critically one of them is caused by a lack of mastering the concepts and learning material [5]. It is important to know students' critical thinking skills in each learning material. One of them is science that is closely related to daily life [6].

The science process skills are also an important link to student success as students. It is to solve problems and find practical solutions [7]. The science process skills are divided into two; basic science process skills and integration [8]. Basic process skills will be the basis for the development of integrated skills. Basic science process skills include observing, classifying, predicting, measuring, inferring, and communicating [9]. Integration science process skills include identifying variables, making data tables, making graphs, describing relationships between variables, collecting and organizing data, analyzing experiments, making hypotheses, defining variables operationally, designing experiments, conducting 
experiments [10]. Both of these science process skills will have an effect on students to solve problems in the environment practically.

Achieving good process skills and critical thinking requires serious effort [11]. Student conditions and student facilities in learning at school will have an influence on learning achievement. The achievement of learning bias is influenced by the skills of the [1] skills and the ability to think critically [12]. However, learning achievement is greatly influenced by many factors. Some researches explain that process skills and critical thinking affect learning outcomes [13]. However, the results of previous studies still have limitations on the location of the study; so that in this study pay attention to addition of urban and rural research locations. Variety of the sample will provide new research results and has rich knowledge.

The focus of research is to see what and how big is the relationship between process skills and critical thinking in junior high school students in learning science? Critical thinking intended is elementary clarification; basic support; inference; advanced clarification; strategies and tactics. The intended science process skills are measure; prediction; communication; conclude; arrange table data; making graphics; obtain and process data; make a hypothesis. In addition, this study also provides a comparison of science process skills and critical thinking of junior high school students in urban and rural areas in science learning.

\section{RESEARCH METHOD}

The science process skills that are of concern to researchers are the process skills popularized by Darmaji, et al. [14]. Researcher was focus on four basic science process skills and four integrated science process skills. Whereas critical thinking that was adopted from Aminudin [4] had five indicators. The study used a mixed method-explanatory approach. Qualitative data is taken after quantitative data [15]. The implementation of this research can be seen in Figure 1. The research sample was taken using a total sampling technique. This sample was taken from eighth-grade students of junior high school who were studying fluid. The total number is 689 students, 376 from urban and 313 students from rural.

The observation instruments for science process skills and multiple choices for critical thinking, and an interview guide for strengthening the data for science process skills and critical thinking. The process skills observation sheet consists of 44 items to measure 7 items; 5 item prediction; 4 item communication; summing up 4 items; compile data table 6 items; graph 4 items; obtain and process data 6 items; make a hypothesis 8 items. All items use a scale of 1-4. While critical thinking consists of 7 questions for each indicator with 1 being the correct score and 0 for the incorrect score. The critical thinking skill instrument has been empirically tested, in order to obtain information regarding the validity and reliability, which was 0.70 and 0.91 respectively. Quantitative approach was describing the result of descriptive, regression, and independent sample t-tests. The categories of observation of science process skills, and multiple choices to assess the critical thinking of students include poor, fair, good, and excellent as shown on Table 1.

Furthermore, the data collection procedure is shown in Figure 1. Quantitative data was gathered; interviews were also conducted. After all questionnaire data were obtained, the data were analyzed, as well as interview data which were further analyzed of interviewed of 10 students from urban and rural. It results of interview to help the statistical data obtained [16].

Table 1. Categories scored of study

\begin{tabular}{|c|c|c|c|c|c|}
\hline \multirow{2}{*}{ Category } & \multicolumn{5}{|c|}{ Basic science process skills } \\
\hline & Observation & Classification & Prediction & \multicolumn{2}{|c|}{ Measure } \\
\hline Poor & $7.0-12.2$ & $5.0-8.7$ & $4.0-7.0$ & \multicolumn{2}{|c|}{$4.0-7.0$} \\
\hline Fair & $12.3-17.5$ & $8.8-12.5$ & $7.1-10.0$ & \multicolumn{2}{|c|}{$7.1-10.0$} \\
\hline Good & $17.6-22.7$ & $12.6-16.2$ & $10.1-13.0$ & \multicolumn{2}{|c|}{$10.1-13.0$} \\
\hline Excellent & $22.8-28.0$ & $16.3-20$ & $13.1-16.0$ & \multicolumn{2}{|c|}{$13.1-16.0$} \\
\hline & \multicolumn{5}{|c|}{ Integrated science process skills } \\
\hline Category & $\begin{array}{c}\text { Variable } \\
\text { Identification }\end{array}$ & $\begin{array}{c}\text { Compile Data } \\
\text { Tables }\end{array}$ & $\begin{array}{c}\text { Make a } \\
\text { hypothesis }\end{array}$ & \multicolumn{2}{|c|}{ Make a graph } \\
\hline Poor & $6.0-10.5$ & $4.0-7.0$ & $6.0-10.5$ & \multicolumn{2}{|c|}{$8.0-14.0$} \\
\hline Fair & $10.6-15.0$ & $7.1-10.0$ & $10.6-15.0$ & \multicolumn{2}{|c|}{$14.1-20.0$} \\
\hline Good & $15.1-19.5$ & $10.1-13.0$ & $15.1-19.5$ & \multicolumn{2}{|c|}{$20.1-28.0$} \\
\hline Excellent & $19.6-24$ & $13.1-16.0$ & $19.6-24$ & \multicolumn{2}{|c|}{$28.1-36.0$} \\
\hline & \multicolumn{5}{|c|}{ Critical thinking } \\
\hline Category & $\begin{array}{l}\text { Elementary } \\
\text { clarification }\end{array}$ & $\begin{array}{c}\text { The basic for } \\
\text { decision }\end{array}$ & Inference & $\begin{array}{l}\text { Advanced } \\
\text { clarification }\end{array}$ & $\begin{array}{c}\text { Strategy and } \\
\text { tactics }\end{array}$ \\
\hline Very low & $0.0-1.4$ & $0.0-1.4$ & $0.0-1.4$ & $0.0-1.4$ & $0.0-1.4$ \\
\hline Low & $1.5-2.8$ & $1.5-2.8$ & $1.5-2.8$ & $1.5-2.8$ & $1.5-2.8$ \\
\hline Fair & $2.9-4.2$ & $2.9-4.2$ & $2.9-4.2$ & $2.9-4.2$ & $2.9-4.2$ \\
\hline High & $4.3-5.6$ & $4.3-5.6$ & $4.3-5.6$ & $4.3-5.6$ & $4.3-5.6$ \\
\hline Very High & $5.7-7.0$ & $5.7-7.0$ & $5.7-7.0$ & $5.7-7.0$ & $5.7-7.0$ \\
\hline
\end{tabular}




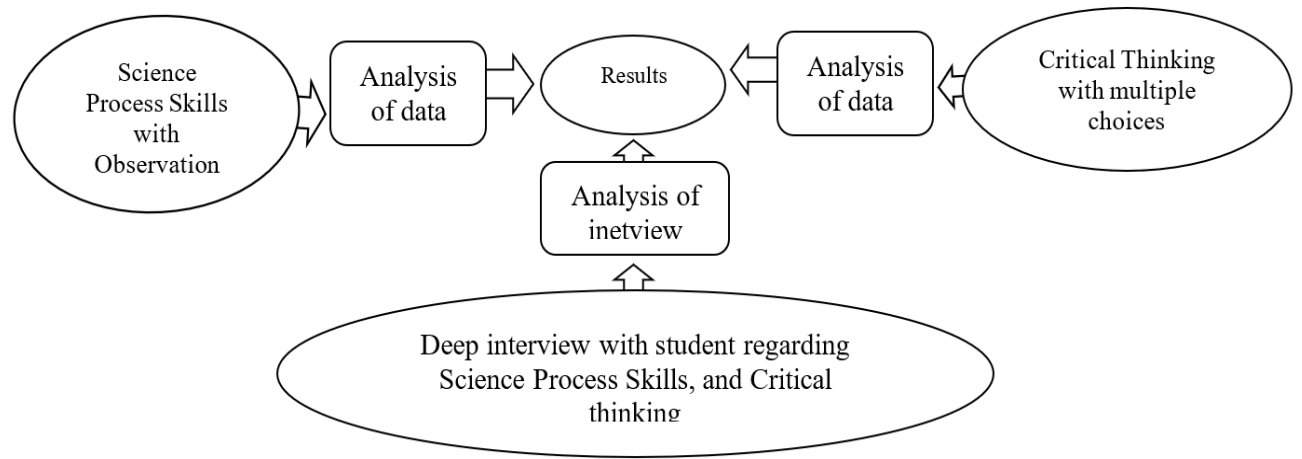

Figure 1. Data collection of this study

\section{RESULTS AND DISCUSSION}

The novelty of this study explores the science processing skills and critical thinking of students' junior high schools. The results explained the data obtained in terms of frequency, mean score, percentage, regression, and independent-sample t-test.

\subsection{Science process skills of students' in urban and rural schools}

The result of students basic and integration science process skills in science subject of fluida at urban junior high schools shown in Table 2, meanwhile for rural schools' area shown in Table 3. Table 2 shows that the mean score of Basic science process skill and integrated science process skill of students in urban area is quite similar. In Basic science process skill, students performed better in classification aspect $(\mathrm{M}=21.32)$. On the other hand, in Integrated science process skill, students gained the high score on make a graph $(\mathrm{M}=24.20)$.

Table 2. Science process skill of students in learning science for urban junior high school

\begin{tabular}{clcccccc}
\hline \multirow{2}{*}{ Science process skill } & \multicolumn{4}{c}{ Category (f \%) } & \multirow{2}{*}{ Total } & \multirow{2}{*}{ Mean } \\
& Observation & Poor & Fair & Good & Excellent & & \\
\hline \multirow{5}{*}{ Basic } & $35(9.3)$ & $87(23.1)$ & $189(50.3)$ & $65(17.3)$ & 376 & 18.04 \\
& Classification & $12(3.2)$ & $88(23.4)$ & $199(52.9)$ & $77(20.5)$ & 376 & 21.32 \\
& Prediction & $24(6.4)$ & $98(26.1)$ & $191(50.8)$ & $64(17.0)$ & 376 & 15.00 \\
& Measure & $9(2.4)$ & $77(20.5)$ & $178(47.3)$ & $80(21.3)$ & 376 & 12.06 \\
& Variable identification & $15(4.0)$ & $98(26.1)$ & $187(49.7)$ & $76(20.2)$ & 376 & 18.16 \\
\multirow{5}{*}{ Integrated } & Compile data tables & $30(8.0)$ & $66(17.6)$ & $202(53.7)$ & $78(20.7)$ & 376 & 12.23 \\
& Make a hypothesis & $22(5.9)$ & $95(25.3)$ & $189(50.3)$ & $70(18.6)$ & 376 & 18.10 \\
& Make a graph & $25(6.6)$ & $89(23.7)$ & $197(52.4)$ & $65(17.3)$ & 376 & 24.20 \\
\hline
\end{tabular}

Table 3. Science process skill of students in learning science for rural junior high school

\begin{tabular}{clcccccc}
\hline \multirow{2}{*}{ Science process skill } & \multicolumn{3}{c}{ Category (f \%) } & \multirow{2}{*}{ Total } & \multirow{2}{*}{ Mean } \\
& Observation & Poor & Fair & Good & Excellent & & \\
\hline \multirow{6}{*}{ Basic } & $73(23.3)$ & $109(34.8)$ & $91(29.1)$ & $40(12.8)$ & 313 & 12.39 \\
& Classification & $88(28.1)$ & $99(31.6)$ & $89(28.4)$ & $37(11.8)$ & 313 & 14.29 \\
& Prediction & $78(24.9)$ & $101(32.3)$ & $91(29.1)$ & $43(13.7)$ & 313 & 7.60 \\
& Measure & $78(24.9)$ & $101(32.3)$ & $91(29.1)$ & $43(13.7)$ & 313 & 8.28 \\
& Variable identification & $81(25.9)$ & $98(31.3)$ & $101(32.3)$ & $33(10.2)$ & 313 & 13.07 \\
& Compile data tables & $67(21.4)$ & $121(38.7)$ & $89(28.4)$ & $37(11.8)$ & 313 & 8.21 \\
& Integrated & $77(24.6)$ & $89(28.4)$ & $108(34.5)$ & $39(12.5)$ & 313 & 16.12 \\
& Make a hypothesis & $75(24.0)$ & $91(29.1)$ & $105(33.5)$ & $42(13.4)$ & 313 & 16.82 \\
\hline
\end{tabular}

Table 3 shows that the mean score of basic and integrated science process skill of students in rural area is quite similar. In Basic science process skill, students performed better in classification aspect $(\mathrm{M}=$ 21.32) and poor in prediction aspect $(M=7.60)$. Integrated science process skill of students gained the high score on make a graph $(\mathrm{M}=24.20)$ and poor in Compile data tables aspect $(\mathrm{M}=21.4)$. The science process skills of students are good for urban areas, but for rural areas, it is still fair. This indicates that there is a gap between urban and rural. A very possible cause is the quality and facilities of learning support. Good facilities make students more enthusiastic in learning and facilitate access to education [17]. This was revealed by several rurals' students related responses in the interview, as follows: 

"... if I can observe the tool, but for use it. I can't. This is my first experience using this tool

It can be seen that students in the area have lack practical experience. This experience is very supportive in conducting practical work and science process skills. Furthermore, for urban, students have a fairly good ability to respond to problems and have to predict, as follows:

"... it is predicted that the viscosity will be large if the mass is large ..., I just estimate it from the formula ..."

Student answers above indicate that students have critical thinking. Process skills are part of the psychomotor skills students must have [18]. Process skills are acquired skills and basic skills, where these basic skills will develop higher skills. To increase this pregnancy requires experience to do the practicum [8]. Science process skills can be used by students to solve science problems in everyday life. Learning models can influence students' science process skills [19]. If the learning model is in accordance with the interests of students, then students' interest in learning will be high and can improve skills, especially in practical learning models. This certainly must be adjusted to the provisions contained in the curriculum. Moreover, the curriculum used is a process-based curriculum. The process-based curriculum will benefit from improving science process skills. Even so, it must be supported by teachers who have good experience [20].

\subsection{Critical thinking of students in urban and rural schools}

The result of student's critical thinking includes; elementary clarification, basic for decision, inference, advanced clarification, strategy and tactics in science for urban schools shown in Table 4, meanwhile for rural schools' area shown in Table 5. Table 4 shows that the mean score of critical thinking of students in urban area is quite similar. Critical thinking of students performed better in Basic for decision and Advanced clarification aspect $(\mathrm{M}=5.08)$ and poor in Elementary clarification aspect $(\mathrm{M}=12.06)$.

Table 4. Critical thinking of students in learning science for urban junior high school

\begin{tabular}{cccccccc}
\hline \multirow{2}{*}{ Critical thinking } & \multicolumn{5}{c}{ Category (f, \%) } & \multirow{2}{*}{ Total } & \multirow{2}{*}{ Mean } \\
\hline Elementary clarification & $12(3.2)$ & $78(20.7)$ & $88(23.4)$ & $174(46.3)$ & $24(6.4)$ & 376 & 5.04 \\
Basic for decision & $4(1.1)$ & $74(19.7)$ & $88(23.4)$ & $182(48.4)$ & $28(7.4)$ & 376 & 5.08 \\
Inference & $11(2.9)$ & $78(20.7)$ & $87(23.1)$ & $176(46.8)$ & $24(6.4)$ & 376 & 5.04 \\
Advanced clarification & $13(3.5)$ & $67(17.8)$ & $84(22.3)$ & $170(45.2)$ & $42(11.2)$ & 376 & 5.08 \\
Strategy and tactics & $4(1.1)$ & $78(20.7)$ & $98(26.1)$ & $156(41.5)$ & $40(10.6)$ & 376 & 5.05 \\
\hline
\end{tabular}

Table 5. Critical thinking of students in learning science for rural junior high school

\begin{tabular}{cccccccc}
\hline \multirow{2}{*}{ Critical thinking } & \multicolumn{3}{c}{ Category (f, \%) } & High & Very High & Total & \multirow{2}{*}{ Mean } \\
\hline Elementary clarification & $19(6.1)$ & $77(24.6)$ & $115(36.7)$ & $89(28.4)$ & $17(5.4)$ & 313 & 3.48 \\
Basic for decision & $20(6.4)$ & $82(26.2)$ & $121(38.7)$ & $81(25.9)$ & $9(2.9)$ & 313 & 3.42 \\
Inference & $25(8.0)$ & $76(24.3)$ & $120(38.3)$ & $81(25.9)$ & $11(3.5)$ & 313 & 3.43 \\
Advanced clarification & $31(9.9)$ & $83(26.5)$ & $101(32.3)$ & $83(26.5)$ & $15(4.8)$ & 313 & 3.42 \\
Strategy and tactics & $24(7.7)$ & $81(25.9)$ & $114(36.4)$ & $73(23.3)$ & $21(6.70)$ & 313 & 3.43 \\
\hline
\end{tabular}

Table 5 shows that the mean score of critical thinking of students in urban area is quite similar. Critical thinking of students performed better in Elementary clarification aspect $(\mathrm{M}=3.48)$ and poor in Advanced clarification and Basic for decision aspect $(\mathrm{M}=3.42)$. For critical thinking skills are not much different from science process skills. Students in urban areas tend to be better than rural in terms of critical thinking. Following are the results of interviews that illustrate, students in rural areas have critical thinking.

"... I try to understand by looking at my father when measuring rice fields ..."

"... yes. I try to apply to flow through my rice field related vessel concepts ... "

Students in rural areas tend to utilize knowledge with the environment they experience. This is very useful and very impressive learning. Because the principle of learning knows what is not known by students, starting from phenomena and concepts [21]. Students must understand the concepts to improve critical thinking [22]. If students have critical thinking skills, students can look at the situation from all sides, able to think ideally [23].

Do a science process skills affect on critical thinking in science? Differences in urban and rural (Darmaji) 
Critical thinking is the main capital to be a problem solver [24]. To produce students who are able to become problem solvers, a strong understanding of concepts is needed [25]. Even natural science subjects that have various concepts will actually help in solving problems in the environment. Some experts claim that: critical thinking skills can be created by giving students treatments. The treatments used to adjust to students' potential, such as learning by playing roles. If students have critical thinking skills, students will tend to have good learning outcomes. Learning achievement can be in the form of critical thinking and have good process skills or a good attitude towards natural science [26]. The method that can be used is to give students problems that require critical thinking [27].

\subsection{The regression between students' science process skills and critical thinking}

For the results of the influence of students' science process skills and critical thinking can be seen in Table 6 and Table 7. From Table 6, it can be seen the results of a simple regression test found that the regression equation is $\mathrm{Y}=17.445+3.267 \mathrm{X}$, where it is found that students' attitudes influence students' critical thinking $(\mathrm{p}<0.001)$.

Table 6. Results of regression

\begin{tabular}{|c|c|c|c|c|c|}
\hline Variable & $\begin{array}{c}\text { Unstandar } \\
\text { B }\end{array}$ & $\begin{array}{l}\text { Coefficients } \\
\text { Std. Error }\end{array}$ & $\begin{array}{l}\text { Standardized Coefficients } \\
\text { Beta }\end{array}$ & $\mathrm{t}$ & sig. \\
\hline Constant & 17.445 & 3.216 & & 7.120 & .000 \\
\hline Science process skill & 3.267 & .731 & .717 & 2.134 & .016 \\
\hline
\end{tabular}

Table 7. Contribution from attitude on self-confidence

\begin{tabular}{ccccc}
\hline Model & R & R square & Adjust R Square & Std. Error of the Estimate \\
\hline 1 & .624 & .515 & .509 & 1.719 \\
\hline
\end{tabular}

The results of simple regression analysis based on Table 7 showed that the value of coefficient of determination was $\left(\mathrm{R}^{2}\right)$ 0.515, this means that the contribution of students' attitude to students' critical thinking is $51.5 \%$, while the remaining $48.5 \%$ is influenced by other variables. From Table 8 it is found that the influence of science process skills on critical thinking is quite significant and from Table 9 it is found that $51.5 \%$ critical thinking is influenced by process skills. There are student responses that illustrate the effect of process skills on critical thinking, as follows:

"... at school, I never did that, so when I can't pump water. I think it's a problem because there is a leak. The same principle is Boyle's law. Water will go in all directions; this is my answer related to related concepts in my life ..."

It is known that students have critical thinking by relating concepts to the problems being faced. From statistical analysis and in-depth interviews, it is concluded that there is an influence of science process skills on students' critical thinking skills. Students who have high ability skills will tend to have the ability to think highly critical thinking. A science process skills indicator, there is an indicator of the ability to think critically. If students master the science process skills of eating students also have critical thinking. This is the same only with the results of research conducted by [28] seen that science process skills have a strong relationship with critical thinking, students with low science process skills have moderate or low critical thinking skills.

\subsection{Differences students' science process skills and critical thinking based on urban and rural area}

The difference between science process skill and critical thinking of student based on urban and rural schools' area is resented in Table 8. This table shows students' science processing skills in, meanwhile Table 9 shows students' critical thinking in learning science subject.

Table 8. Independent sample t-test for science process skill

\begin{tabular}{|c|c|c|c|c|c|c|c|c|}
\hline & \multirow{2}{*}{ School area } & \multirow{2}{*}{ Mean } & \multirow{2}{*}{ Std. Deviation } & & \multirow{2}{*}{ df } & \multirow{2}{*}{ Sig. } & \multicolumn{2}{|c|}{ 95\% confidence interval } \\
\hline & & & & & & & Lower & Upper \\
\hline \multirow{2}{*}{ Science process skill } & Urban & 3.175 & .17825 & 18.224 & 687 & 0.001 & 14.330 & .6250 \\
\hline & Rural & 2.482 & .18190 & 18.224 & 683.125 & & 11.335 & .7125 \\
\hline
\end{tabular}


Based on the Table 8, result shows if that there is a significance differences between students' science process skills in learning science in urban school and rural school $(\mathrm{t}(687)=18.224, \mathrm{p}<0.01)$, where students who are schooling in urban schools' area $(\mathrm{M}=3.175, \mathrm{SD}=0.17825)$ tent to provide higher attitudes than students who are schooling in rural schools' area $(\mathrm{M}=2.482, \mathrm{SD}=0.18190)$. This value illustrates the difference in the ability of students in urban and rural areas. This impact will have a significant effect on critical thinking, as in Table 9.

Table 9. Independent sample t-test for critical thinking

\begin{tabular}{ccccccccc}
\hline & \multirow{2}{*}{ School area } & \multirow{2}{*}{ Mean } & \multirow{2}{*}{ Std. Deviation } & \multirow{2}{*}{$\mathrm{T}$} & \multirow{2}{*}{$\mathrm{df}$} & \multirow{2}{*}{ Sig. } & \multicolumn{2}{c}{ 95\% confidence interval } \\
Lower & Upper \\
\hline \multirow{2}{*}{ Critical thinking } & & & & & & & & \\
& Urban & 5.058 & .16330 & 17.224 & 687 & 0.000 & 11.115 & .5560 \\
& Rural & 3.436 & .15220 & 17.221 & 683.225 & & 12.120 & .6265 \\
\hline
\end{tabular}

Furthermore, based on the Table 9, result shows if that there is a significance differences between students' critical thinking in learning science in urban school and rural school $(\mathrm{t}(687)=17.224, \mathrm{p}<0.001)$ ), where students who are schooling in urban schools' area $(\mathrm{M}=5.058, \mathrm{SD}=0.16330)$ tent to provide higher self-confidence than students who are schooling in rural schools' area $(\mathrm{M}=3.436, \mathrm{SD}=0.15220)$.

Critical thinking between urban and rural has a significant difference. The difference in the critical thinking skills of secondary school students can be influenced by many factors. One of them is with the facilities and quality of learning. As stated by [29] Education to acquire knowledge, skills, and habits in life. Education can be said as a conscious effort to shape human potential as the participants do by teaching and facilitating student learning activities. The importance of the science process skills for junior high school students is that students learn meaningfully by knowing and being actively involved in discovering concepts from existing phenomena in the environment. Meaningful learning is learning that involves students directly and learning will be easy to remember [20]. Students who can form science process skills will help students master further skills. Students who have the science process skills then these students will think critically. The ability to think critically is needed in order to understand the concept well [30].

The region problem can influence the science process skills and critical thinking [31]. In addition, the level of student age or grade level will affect science process skills and critical thinking [32] meaning students who already have a lot of knowledge will be more critical and have science process skills. All problems or inhibiting factors can be minimized by the ability of good teachers, by how the teacher cheers students with their shortcomings and needs [33]. So, it is expected that students equally have high critical thinking skills, and can answer future challenges [34].

\section{CONCLUSION}

Science process skill of students in learning science both urban and rural areas are good. However when comparing that results, the independent sample t-test showed that there was a significance difference in students' science process skill in urban school $(\mathrm{M}=3.175, \mathrm{SD}=0.178)$ and in rural schools $(\mathrm{M}=2.482, \mathrm{SD}$ $=0.182) ;(\mathrm{t}(687)=18.224, \mathrm{p}<0.01$. the independent sample t-test showed that there was a significance difference in students' critical thinking in urban school $(\mathrm{M}=5.058, \mathrm{SD}=0.163)$ and in rural schools $(\mathrm{M}=$ $3.436, \mathrm{SD}=0.152) ; \mathrm{t}(687)=17.224, \mathrm{p}<0.001$. Students' science process skill affects critical thinking in learning science $\left(\mathrm{R}^{2}=0.515\right.$ or $\left.51.5 \%\right)$. The implication of this study is that the process skills and critical thinking of students must be reviewed and improved for the achievement of science learning, especially in rural areas.

\section{REFERENCES}

[1] Kurniawan, Wawan, et al., "Multimedia physics practicum reflective material based on problem solving for science process skills," International Journal of Evaluation and Research in Education, vol. 8, no. 4, pp. 590-595, 2019.

[2] Jung, Hwa-Yoon, et al., "Effects of a simulation-based Korean Advanced Life Support (KALS) program on knowledge, confidence, and critical thinking disposition for paramedic students," The Korean Journal of Emergency Medical Services, vol. 24, no. 1, pp. 57-66, 2020.

[3] H. Siegel and C. Gables, "Critical Thinking," in International Encyclopedia of Education, (3 $3^{\text {rd }}$ edition), Elsevier Ltd, pp. 141-145, 2010.

[4] A. H. Aminudin, D. Rusdiana, A. Samsudin, L. Hasanah, and J. Maknun, "Measuring critical thinking skills of 11th grade students on temperature and heat," J. Phys. Conf. Ser., vol. 1280, no. 5, pp. 1-5, 2019.

[5] P. D. Sundari, Parno, and S. Kusairi, "Students' Critical Thinking Ability in Integrated Learning Model (in bahasa)," J. Kependidikan, vol. 2, no. 2, pp. 348-360, 2018. 
[6] Silveira, et al., "Science learning: an analysis of discursive interactions and different space-temporal dimensions in the classroom daily life," Revista Brasileira de Educação, vol. 25, pp. 1-31, Apr. 2020.

[7] D. Darmaji, et al., "An Identification of Science Pre-Service Teachers' Science Process Skills through Science Process Skills-Based Practicum Guidebook," J. Ilm. Pendidik. Fis. Al-Biruni, vol. 7, no. 2, pp. 239-245, 2018.

[8] N. Hırça, "The influence of hands on science experiments on scientific process skills according to prospective teachers' experiences," Eur. J Phys. Educ., vol. 4, no. 1, pp. 1-9, 2012.

[9] R. G. Raj and S. N. Devi, "Science process skills and achievement in science among high," Sch. Res. J. Interdiscip. Stud., vol. 2, no. 15, pp. 2435-2443, 2014.

[10] V. M. Chabalengula, F. Mumba, and S. Mbewe, "How pre-service teachers' understand and perform science," Eurasia J. Math. Sci. Technol. Educ., vol. 8, no. 3, pp. 167-176, 2012.

[11] D. Dakabesi, et al., "The effectiveness of problem-based learning model to increase the students' critical thinking skills," Journal of Education and Learning (EduLearn), vol. 13, no. 4, pp. 543-549, 2018

[12] T. M. Sholihah and B. Lastariwati, "Problem based learning to increase competence of critical thinking and problem solving," Journal of Education and Learning (EduLearn), vol. 14, no. 1, pp. 148-154, 2020.

[13] Syahrial, Asrial, et al., "Towards improving the critical thinking skills of pre-service teachers in Indonesia," Journal of Education and Learning (EduLearn), vol. 13, no. 4, pp. 575-582, 2019.

[14] Darmaji, D., Kurniawan, D. A., and Irdianti, I., "Physics Education Students' Science Process Skills," International Journal of Evaluation and Research in Education, vol. 8, no. 2, pp. 293-298, 2019.

[15] J. W. Creswell, Designing and conducting mixed methods research (3rd Ed.), Thousand Oaks, CA: Sage Publications, 2018.

[16] L. Cohen, L. Manion, and K. Morrison, Research methods in education, New York: Routledge, 2017.

[17] Servitri, Margaretha Ordo, and Wulan Trisnawaty, "The development of inquiry science worksheet to facilitate the process skills," Journal of Education and Learning (EduLearn), vol. 12, no. 4, pp. 575-580, 2018.

[18] Puspita, Kurniawati, and Suwarma, "Analysis of critical thinking skills on the topic of static fluid analysis of critical thinking skills on the topic of static fluid," Int. Conf. Math. Sci. Educ., vol. 895, pp. 1-4, 2017.

[19] I. Limatahu, et al., "Development of CCDSR teaching model to improve science process skills of pre-service science teachers," Journal of Baltic Science Education, vol. 17, no. 5, pp. 812-827, 2018.

[20] B. A. Danday and S. L. C. Monterola, "Effects of microteaching science lesson study on pre-service teachers," Journal of Baltic Science Education, vol. 18, no. 5, pp. 692-707, 2019.

[21] D. T. Tiruneh, and M. De. Cock, "Measuring critical thinking in science: Development and validation of a critical thinking test in electricity and magnetism," International Journal of Science and Mathematics Education, vol. 15, no. 4, pp. 663-682, 2016.

[22] F. Seroglou and P. Koumaras, "The contribution of the history of science in science education: A review," in Bevilacqua F., Giannetto E., Matthews M. (eds), Scince Educ. and Cult., Springer, Dordrecht, pp. 327-346, 2001.

[23] A. O. Olaniyan and N. Govender, "Effectiveness of polya problem-solving and target-task collaborative learning approaches in electricity amongst high school science students," Journal of Baltic Science Education, vol. 17, no. 5, pp. 765-777, 2018.

[24] Utomo, et al., "Diversification of reasoning science test items of timss grade 8 based on higher order thinking skills: A case study of Indonesian," Journal of Baltic Science Education, vol. 17, no. 1, pp. 152-161, 2018.

[25] N. Sener, and E. Tas, "Improving of students' critical thinking through purdue model in science," Journal of Baltic Science Education, vol. 16, no. 3, pp. 350-365, 2017.

[26] D. Gurcay and H. O. Ferah, "The Effects of multiple intelligences-based instruction on students' science achievement and attitudes," Journal of Baltic Science Education, vol. 16, no. 5, pp. 666-677, 2017.

[27] R. Zenda and J. Ferreira, "Improving academic achievement of science students in rural schools through assessment practices: A South African case study," J. of Baltic Science Education, vol. 15, no. 4, pp. 523-531, 2016.

[28] Mahanal, Susriyati, et al., "RICOSRE: A learning model to develop critical thinking skills for students with different academic abilities," International Journal of Instruction, vol. 12, no. 2, pp. 417-434, 2019.

[29] Asrial, Syahrial, D. A. Kurniawan, R. Perdana, and P. Nugroho, "Supporting technology 4.0: Ethoconstructivist multimedia for elementary schools," Int. J. online Biomed. Eng., vol. 15, no. 14, pp. 54-66, 2019.

[30] A. H. Zeidan and M. R. Jayosi, "Science process skills and attitudes toward science among palestinian secondary school students," World J. Educ., vol. 5, no. 1, pp. 13-24, 2015.

[31] S. Mupezeni and J. Kriek, "Out-of-school activity: A comparison of the experiences of rural and urban participants in science fairs in the limpopo province, south africa," EURASIA J Math Sci Tech Ed, vol. 14, no. 8, pp. 6-12, 2018.

[32] B. A. Prayitno, et al., "Closing the science process skills gap between students with high and low level academic achievement," Journal of Baltic Science Education, vol. 16, no. 2, pp. 266-277, 2017.

[33] X. Zhan, et al., "Propensity score analysis of the impacts of junior secondary students' participation in engineering practices on their attitudes toward engineering," EURASIA J Math Sci Tech Ed, vol. 15, no. 11, pp. 5-17, 2019.

[34] G. S. Selçuk, "The effects of problem-based learning on pre-service teachers' achievement, approaches and attitudes towards learning science,” International Journal of Physical Sciences, vol. 5, no. 6, pp. 711-723, 2010. 